\title{
Ramsay Hunt Syndrome: Case Report
}

\section{Síndrome Ramsay Hunt: Caso Clínico}

Vasco Carvalho ${ }^{1 *}$, Sofia Martins ${ }^{1}$

*Corresponding Author/Autor Correspondente: Vasco Carvalho [vascofonsecacarvalho@gmail.com]

KEYWORDS: Child; Herpes Zoster Oticus/diagnosis; Herpes Zoster Oticus/therapy

PALAVRAS-CHAVE: Criança; Herpes Zoster Oticus/diagnóstico; Herpes Zoster Oticus/tratamento

An 11-year-old girl presented to our emergency department with a 2-day history of nausea, vomiting and headache. She denied tinnitus, hipoacusia and vertigo. Her medical history included varicella infection at 5 years of age. Physical examination showed a right sided facial nerve palsy (House-Brackmann Facial Nerve Grading Scale (HB FGS) V). She had crusting vesicular lesions on the right ear pinna (Fig.s 1 and 2). Meningeal signs were negative. Computed tomography (CT) scan and blood analysis were unremarkable. Cerebrospinal fluid (CSF) showed an elevated white cell count (210 u/L) but normal glucose and protein levels. Based on clinical and analytical findings, Ramsay Hunt syndrome complicated with viral meningitis was diagnosed at this point. The pa- tient started oral prednisolone (60 mg/day for 5 days), intravenous acyclovir (1500 mg/m²/day for 10 days) and physical rehabilitation. Subsequent molecular testing of CSF detected varicella zoster virus (VZV) RNA by reverse transcriptase PCR. The follow-up showed disappearance of the earache and vesicular rash, as well as the improvement of facial paralysis, becoming a grade III HBFGS. The one-year follow-up showed no relapse of the syndrome and total recuperation of the initial deficits (Fig. 3).

Ramsay-Hunt syndrome is a rare disease characterized by facial paralysis, inner ear dysfunction, periauricular pain, and herpetiform vesicles (zoster oticus). The reported incidence in children is 2.7/100 000 and it's 


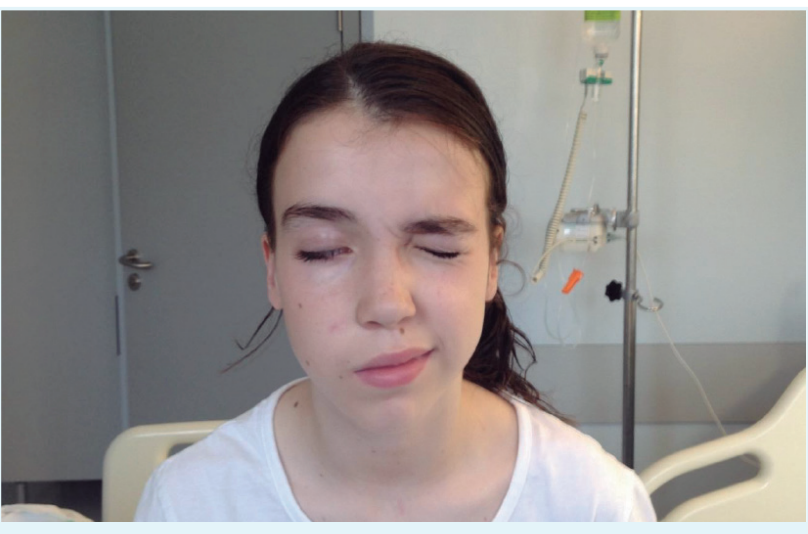

FIGURE 1. Deviation of the left lip commissure, incapacity for total occlusion of the right eye and asymmetry of the wrinkles in the forehead.

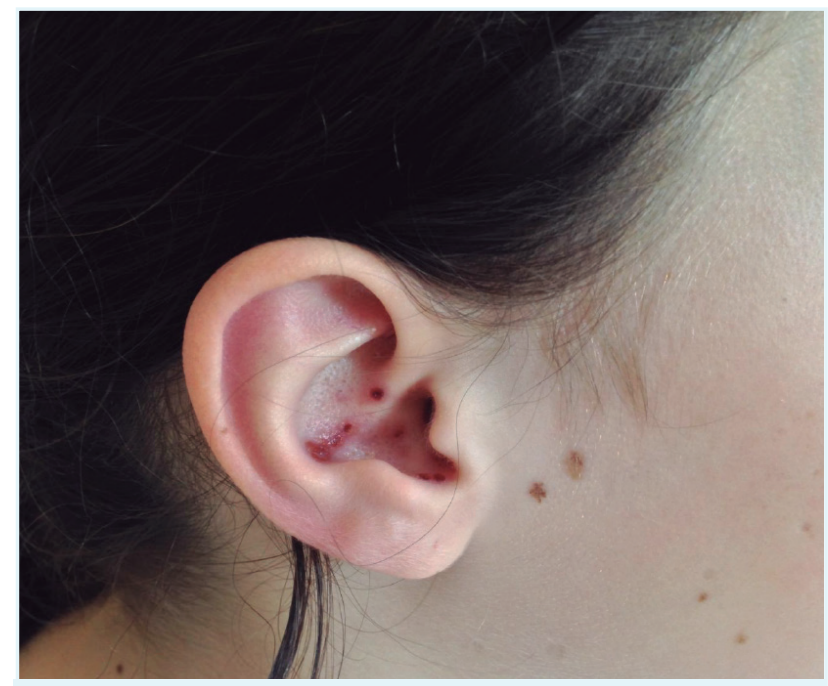

FIGURE 2. Vesicle rash on the right concha.

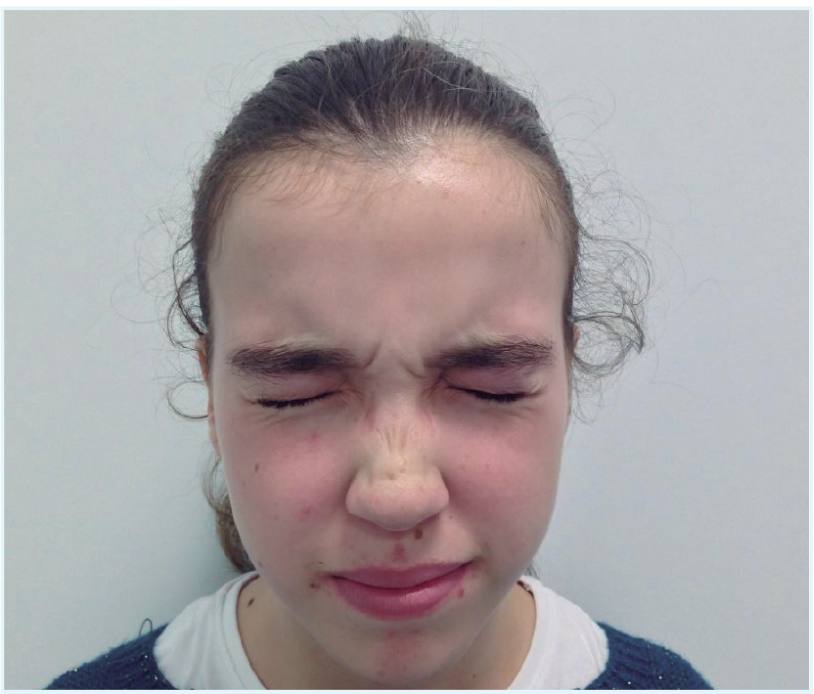

FIGURE 3. Recuperation of the initial deficits.

caused by the reactivation of latent VZV in the geniculate ganglion. ${ }^{1}$ Despite the lack of randomised, controlled prospective treatment trials for Ramsay Hunt syndrome, data from the collective case reports and retrospective reviews suggest that both prednisone and acyclovir, if given early, improve the overall prognosis. A large Ramsay Hunt syndrome treatment study ${ }^{2}$ showed a statistically significant improvement in patients treated with prednisone and acyclovir within 3 days of onset. Further, in the same study, 26 (50\%) patients who were not treated in the first 3 days progressed to a complete loss of response to facial nerve stimulation. ${ }^{3}$

In this case report we intend to emphasize the importance of an early diagnosis of this syndrome so that the treatment is started promptly. The anamnesis and physical exam remain crucial for diagnosing Ramsay Hunt syndrome. PCR to detect $V Z V$ in exudates from the geniculate zone of the ear is sensitive and can confirm the clinical suspicion. Although further research is needed, geniculate zone VZV PCR may help to distinguish between patients with Bell's palsy and patients with early Ramsay Hunt syndrome.

\section{RESPONSABILIDADES ÉTICAS}

CONFLITOS DE INTERESSE: Os autores declaram a inexistência de conflitos de interesse na realização do presente trabalho.

FONTES DE FINANCIAMENTO: Não existiram fontes externas de financiamento para a realização deste artigo.

CONFIDENCIALIDADE DOS DADOS: Os autores declaram ter seguido os protocolos da sua instituição acerca da publicação dos dados de doentes.

CONSENTIMENTO: Consentimento do doente para publicação obtido.

PROVENIÊNCIA E REVISÃO POR PARES: Não comissionado; revisão externa por pares.

\section{ETHICAL DISCLOSURES}

CONFLICTS OF INTEREST: The authors have no conflicts of interest to declare.

FINANCING SUPPORT: This work has not received any contribution, grant or scholarship.

CONFIDENTIALITY OF DATA: The authors declare that they have followed the protocols of their work center on the publication of data from patients.

PATIENT CONSENT: Consent for publication was obtained.

PROVENANCE AND PEER REVIEW: Not commissioned; externally peer reviewed. 


\section{REFERÊNCIAS}

1. Sweeney CJ, Gilden DH. Ramsay Hunt syndrome. J Neurol Neurosurg Psychiatry. 2001;71:149-54. doi: 10.1136/ jnnp.71.2.149.

2. Murakami S, Hato N, Horiuchi J, Honda N, Gyo K, Yanagihara N. Treatment of Ramsay Hunt syndrome with acyclovir-prednisone: significance of early diagnosis and treatment. Ann Neurol. 1997:41:353-7. doi: 10.1002/ana.410410310.

3. Murakami S, Honda N, Mizobuchi M, Nakashiro Y, Hato N, Gyo K. Rapid diagnosis of varicella zoster virus infection in acute facial palsy. Neurology. 1998;51:1202-5. doi: 10.1212/ wnl.51.4.1202. 